\title{
Forest policy goals in Poland in light of the current forestry aims in Europe Part 3. European priorities for the forest policy in Polish programmes and strategies
}

\author{
Adam Kaliszewski \\ Forest Research Institute, Department of Forest Resources Management, Sękocin Stary, ul. Braci Leśnej 3, 05-090 Raszyn, Poland \\ Phone: +48 22 7150678, fax +48 22 7153837, e-mail: A.Kaliszewski@ibles.waw.pl
}

\begin{abstract}
The aim of the paper is to review and evaluate Polish programmes and strategies centred on and related to forest, as well as national and transregional development strategies and priorities formulated at the European level. This work covers the 'National Forest Policy' and 28 other strategies, policies and programmes representing various forest-related policy areas, including environmental protection, agriculture and rural development, climate and energy as well as development strategies from 1997 to 2017.

The study shows that many of the priorities of the European forest policy have not been reflected in the 'National Forest Policy'. These include, among others, adapting forests to climate change and enhancing their mitigation potential, enhancing the economic contribution of forestry to rural development, enhancing the role of the SFM in a green economy, securing the participation of all stakeholders in forest-related decision-making processes, improving communication in forestry and developing cross-sectoral cooperation. However, many of these forest-related issues have already been included in numerous strategic documents of other policy areas. As a result, many European forest policy priorities are scattered across Polish policy documents of different forest-related sectors and it raises justified concerns that inconsistencies and contradictions exist between them. Another matter of significant concern is that the issue of forests and forestry is barely mentioned in any of the examined development strategies. This may also indicate that the forest sector is getting more and more marginalized in the socioeconomic and political sector, as forest policy goals are defined and achieved within other policy areas and are practically absent in national and transregional development strategies.
\end{abstract}

Keywords: Policy analysis, forest-related policies, development strategies, regional development

\section{Introduction}

In April 2017, it has been 20 years since the Council of Ministers has adopted the 'National Forest Policy' defying the main directions of forestry development in Poland (MOŚZNiL 1997). Deep political, economic and social changes have taken place during the last two decades in Poland and Europe. Main reason for socio-economic changes and changes in public awareness was Poland joining the European Union in 2004 and adopting acquis communautaire and its participation in the process of policy forming and drafting the Community law.
Aims and tasks of forest policy in Europe in transregional and the international scales are defined foremost within the Forest Europe process, which concentrates on the European Union and all the European countries, as well as within the European Union itself. Both forums are strongly related and complement each other. Lack of legal possibility for conducting separate forest policy by the European Union causes that forest and forestry are covered with fragmentary regulations within the policies of the other sectors. On the other hand, definition and realization of complex forest policy lies within competition of the Member States.

Received: 23.11.2017, reviewed: 7.05.2018, accepted: 30.07.2018. 
This paper is the third in the series of articles written in order to indicate the justified directions of changes in the 'National Forest Policy' based on the analysis of political processes forming the forest policy in Europe and the trends in forest policy in the selected European countries. This paper describes the results of the content analysis of the Polish strategic documents and programmes directly or indirectly connected with forest and forestry, and also, the general national and transregional development strategies towards the inclusion of the most important priorities formulated within the last two decades in the European forest policy.

\section{Methods}

A starting point of the analysis presented in this paper are the priorities of the forest policy in Europe defined within the Forest Europe process and present in the documents of the European Union. Their characteristics were included in the previous article in this cycle (Kaliszewski 2018). Identified priorities were referred to the Polish strategic documents and programme documents that were adopted in the period from 1997 to 2018 and are directly or indirectly connected to forests and forest management (content analysis; Buttolph Johnson et al. 2010; Weimer, Vining 2011). The analysis concerned documents content as regards inclusion of the priorities of the European forest policy. Besides, the 'National Forest Policy' (MOŚZNiL 1997), to which special attention was given due to comprehensive approach to forest and forestry issues, the study covered 28 strategic documents and programmes. They concerned environmental and biodiversity conservation policies, agricultural and rural development policy, climate and energy policies, spatial planning policy but also national and transregional development strategies. Particularly reviewed were the following documents (according to fields of policy, in the chronological presentation):

1) Forest policy: 'National Forest Policy' (MOŚZNiL 1997), "The State Forests National Forest Holding Strategy 2014-2030" (DGLP 2013)

2) Environmental policy: '2nd National Environmental Policy’ (MŚ 2001), 'National Environmental Policy 20032006 with 2007-2010 outlook' (Uchwała 2002), 'National Strategy for the Conservation of Biodiversity with the Action Plan' (MŚ 2003a), 'National Environmental Policy 2007-2010 with 2011-2014 outlook' (MŚ 2006), 'National Environmental Policy 2009-2012 with an outlook to 2016' (MŚ 2008), 'Programme for Conservation and Sustainable Use of Biodiversity with the Action Plan for years 20152020' (Uchwała 2015b)
3) Agricultural and rural development policy: 'Rural Development Plan 2004-2006' (MRiRW 2004), 'Rural Development Programme 2007-2013' (MRiRW 2007), 'Strategy for Sustainable Development of Rural Areas, Agriculture and Fisheries 2012-2020' (Uchwała 2012b), 'Rural Development Programme 2014-2020' (MRiRW 2014)

4) Climate and energy policies: 'Climate Policy of Poland. The strategies for greenhouse gas emission reductions in Poland until 2020' (MŚ 2003b), 'Energy Policy of Poland until 2030' (Obwieszczenie 2009), 'Poland National Renewable Energy Action Plan until 2020' (MG 2010), 'Polish National Strategy for Adaptation to Climate Change until 2020 with an outlook to 2030' (MŚ 2013), 'Energy Safety and Environment Strategy - with an outlook to 2020' (Uchwała 2014b)

5) Spatial policy: 'National Spatial Development Concept' (Uchwała 2011)

6) Economic policy of the country: 'National Development Strategy 2007-2015' (MRR 2006), 'Poland 2030. Development Challenges' (KPRM 2009), 'National Strategy for Regional Development. Regions, Cities, Rural Areas' (Uchwała 2010), 'Poland 2030. Third Wave of Modernity. Long-term National Development Strategy' (MAiC 2012), 'National Development Strategy 2020. Active society, competitive economy, efficient state' (Uchwała 2012a), 'Strategy for Innovation and Efficiency of the Economy "Dynamic Poland 2020"' (Uchwała 2013a); 'Strategy for Responsible Development until 2020 (with an outlook up to 2030)' (Uchwała 2017)

7) Transregional policy: 'Strategy for Socioeconomic Development of Eastern Poland until 2020' (Uchwała 2013b), 'Strategy for Development of Southern Poland until 2020' (Uchwała 2014a), 'Strategy for Development of Western Poland until 2020' (Uchwała 2014c), 'Strategy for Development of Central Poland until 2020, with an outlook to 2030' (Uchwała 2015a).

\section{Results of research and discussion}

Table 1 presents the results of the review and analysis of 'National Forest Policy' content as well as strategic and programme documents directly or indirectly connected with forests and forest management towards the inclusion of forestry priorities at the European level. The table contains documents defying directions for forest policy, environmental, agricultural and rural development policies, and also climate, energy and spatial policies. On the other hand, Table 2 presents the results of the analysis of national and transregional development strategies.

Analysis of goals of the 'National Forest Policy' from their consistency with the European forest policy point of 
view, indicates that this document, to a large extent, does not reflect the current international trends and overriding goals in forestry. To priorities present and clearly indicated in the 'National Forest Policy', included should be: conservation, protection, restore and proper support of biological diversity (priority no. 1), enhancing forest immunity to abiotic and biotic factors (partly priority no. 2), maintaining and improving forest ecosystem services (priority no. 4), promoting production and use of wood, supporting private forest owners (partly priority no. 6), forest education of society (priority no. 14) and conducting forest research (priority no. 15).

A list of priorities that have not been included at all or have been included indirectly or the approach to the topic was too general in the 'National Forest Policy' is longer. One of those priorities is adapting forests to climate change (priority no. 2), which is currently, and also will be in the coming decades, one of the most important challenges for forestry in Europe (Streck et al. 2010). The same applies to the issue of enhancing the role of forests and forest management in mitigating climate changes (priority no. 3). This topic is not even mentioned in the 'National Forest Policy', except listing the increase in the accumulation of carbon in biomass and forest soil as one of the expected effects of the policy's goals achievement. The document does not include issues concerning the substitution of non-renewable materials and products with wood and the use of wood for energy for production. In this context, it is understandable that there is a lack of references in the "National Forest Policy' regarding the issue of increasing the role of forest sector in a green economy (priority no. 8), which is a relatively new concept disseminated, as a result of the United Nation Conference on Sustainable Development Rio +20 in 2012 (Kohl 2013).

The 'National Forest Policy' does not also raise some other fundamental issues. These are the innovations in forestry and differentiation of sources of income of forest holdings (partly priority no. 6), forest valuation and reflecting it in the forest-related policies and programmes (priority no. 9). On the other hand, issues concerning the increasing role of forests and forest management in rural development (priority no. 7) was included in the document in a very general manner. This happened despite a strong organizational structure and good economic condition of the State Forests Holding and its significant opportunity to influence on the local economy.

Some European priorities are present in the 'National Forest Policy' but were formulated not as goals but conditions, that is, circumstances influencing implementation of tasks. These are issues of developing human resources (partly priority no. 10), preserving cultural value of forests and forest management (priority no. 13) and also institutional issues, in its broadest sense, ensuring participation of stakeholders in the forest-related decision-making process, improvement of communication in forestry (priority no. 11) and fostering coordination and cross-sectoral cooperation of forestry (priority no. 12).

However, it should be emphasized that numerous priorities of European forest policy were included in other Polish programmes and strategies related to forestry (tab. 1). For instance, issues of forest adaptation to climate change (priority no. 2) are brought up in the 'Polish National Strategy for Adaptation to Climate Change until 2020 with an outlook to 2030' (MŚ 2013) and in the 'Strategy: Energy Safety and Environment Strategy' (Uchwała 2014b), and also in the three documents of the environmental policy (Uchwała 2002, MŚ 2006, Uchwała 2015b), the 'Climate Policy of Poland' (MŚ 2003b) and the 'Strategy for Sustainable Development of Rural Areas, Agriculture and Fisheries 2012-2020' (Uchwała 2012b). This issue is also supported by the 'Rural Development Programme 20072013' (MRiRW 2007).

Enhancing the role of forests and forest management in mitigating climate change (priority no. 3 ) is brought up primarily in reference to the increase of the amount of carbon stored in biomass and forest soils (MŚ 2003b, MRiRW 2004, MŚ 2006, MRiRW 2007, MRiRW 2014). Other issues were almost completely omitted (mobilization of wood resources) or occur occasionally (substitution of nonrenewable material and products with wood, promoting wood as a source of energy).

A significant support for forestry priorities on the European level is offered within the agricultural policy. Successive programmes for agriculture and rural development (MRiRW 2004, 2007, 2014) are aimed at, inter alia, increasing the role of forests and forest management (private sector especially), in development of rural areas - mainly by supporting the afforestation of non-state lands, and also other forms of support for forest owners (training for instance). The high significance of rural development programmes is indicated by the fact that managing financial instruments and institutional facilities allows for stepping outside the declarative nature of the undertaken actions. On the other hand, it should be noticed that forestry issues in those programmes are of minor importance.

Among the formulated priorities of the forest policy in Europe indicated can be those that do not find reflection in the 'National Forest Policy' and are only mentioned in the other analysed documents. These priorities are: supporting innovations in forestry (partly priority no. 6), mentioned 
Table 1. Inclusion of the priorities for forestry in Europe into Polish forest-focused and forest-related strategies and programmes Symbols: "+" - a priority directly included; " $(+)$ " - a priority indirectly included; blank field - a priority not included in a document

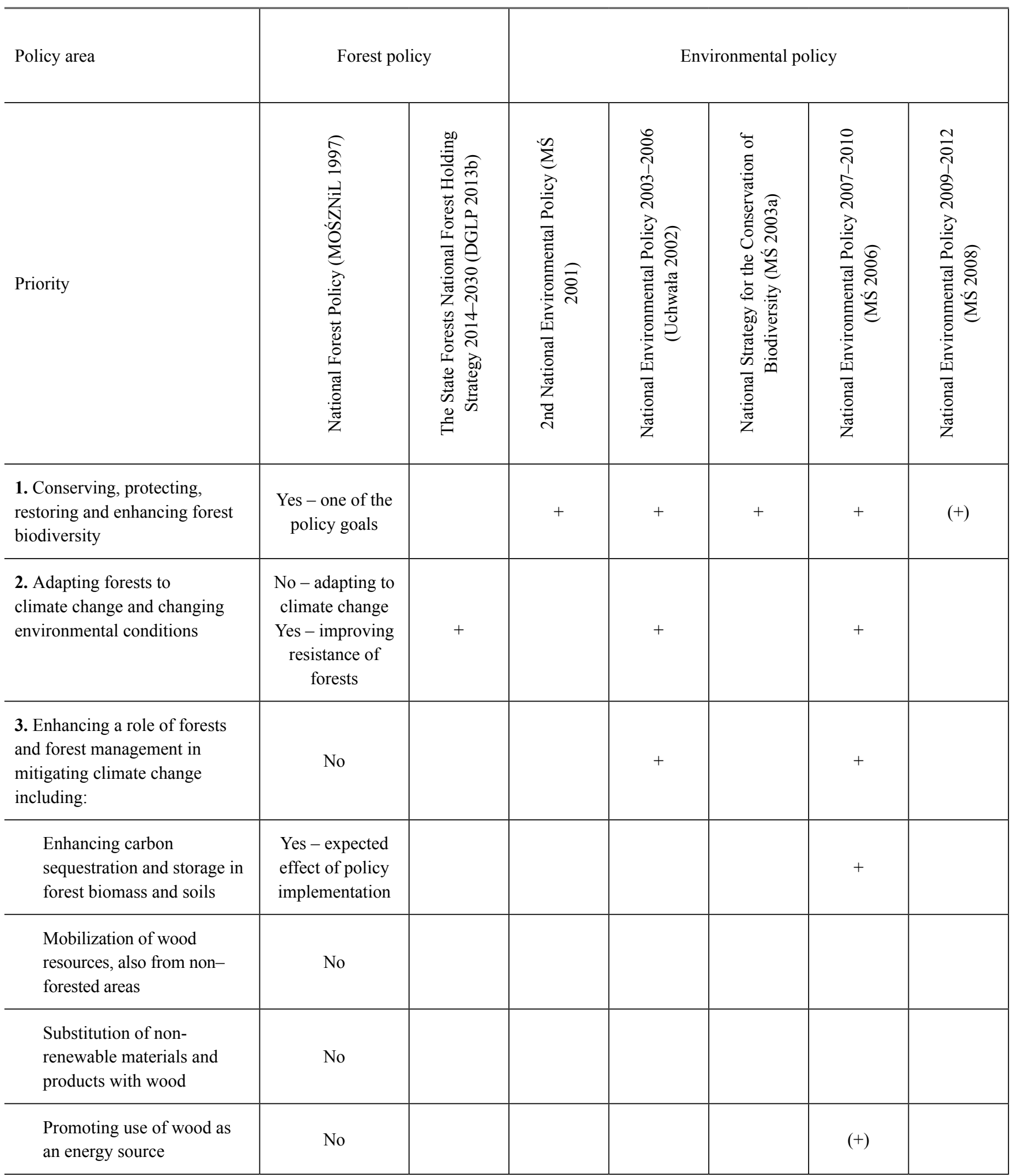




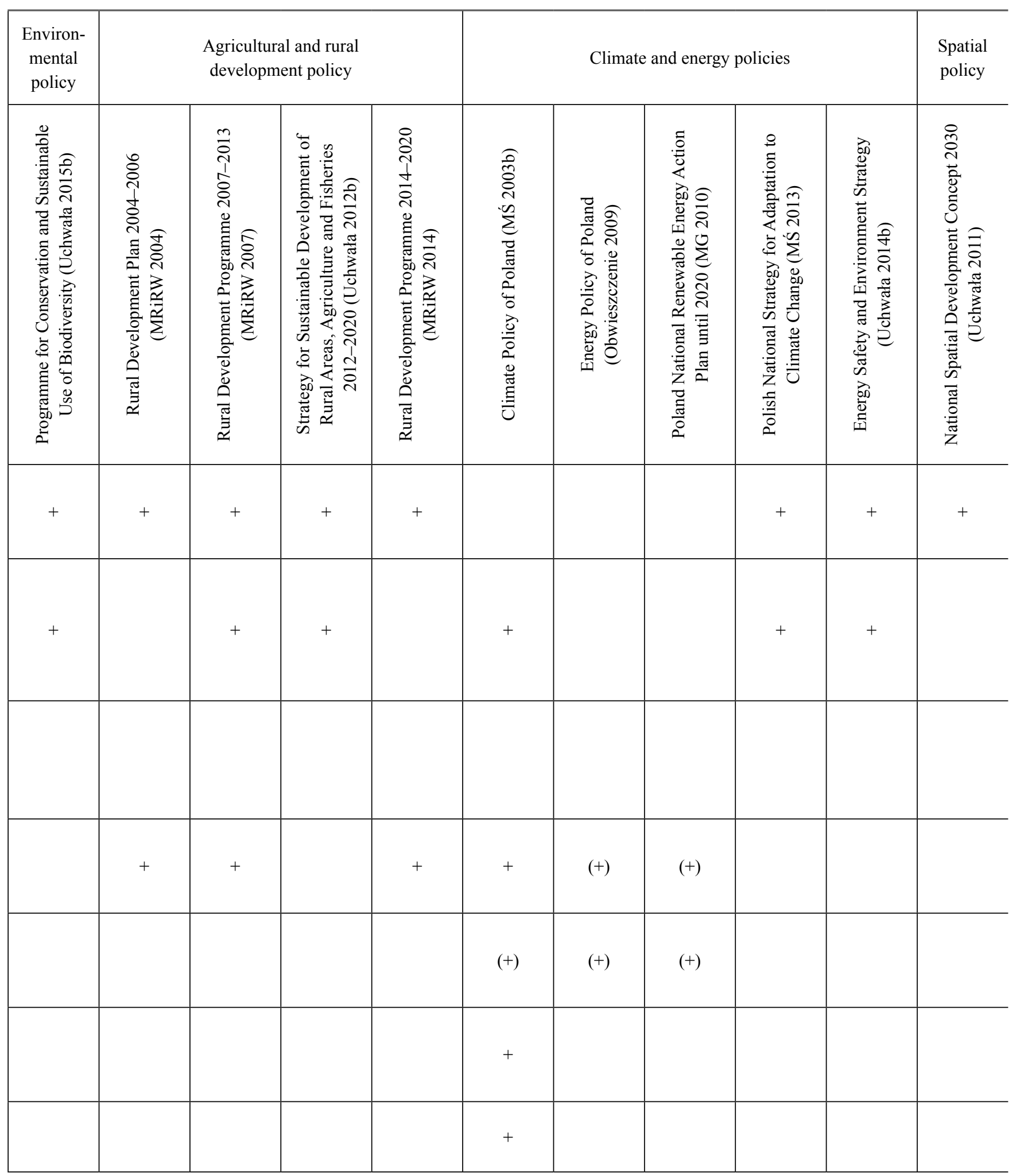




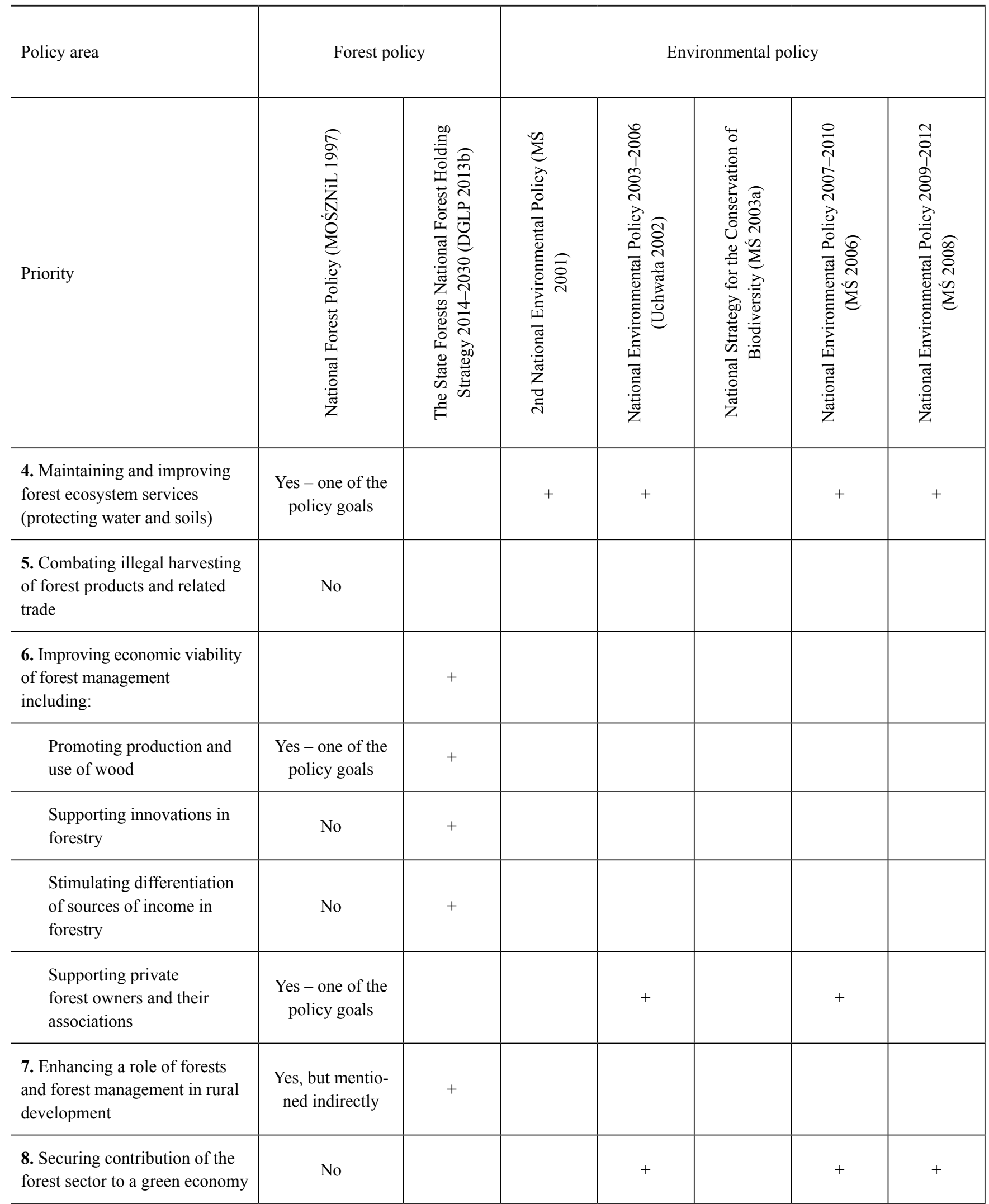


A. Kaliszewski / Leśne Prace Badawcze, 2018, Vol. 79 (3): 211-227

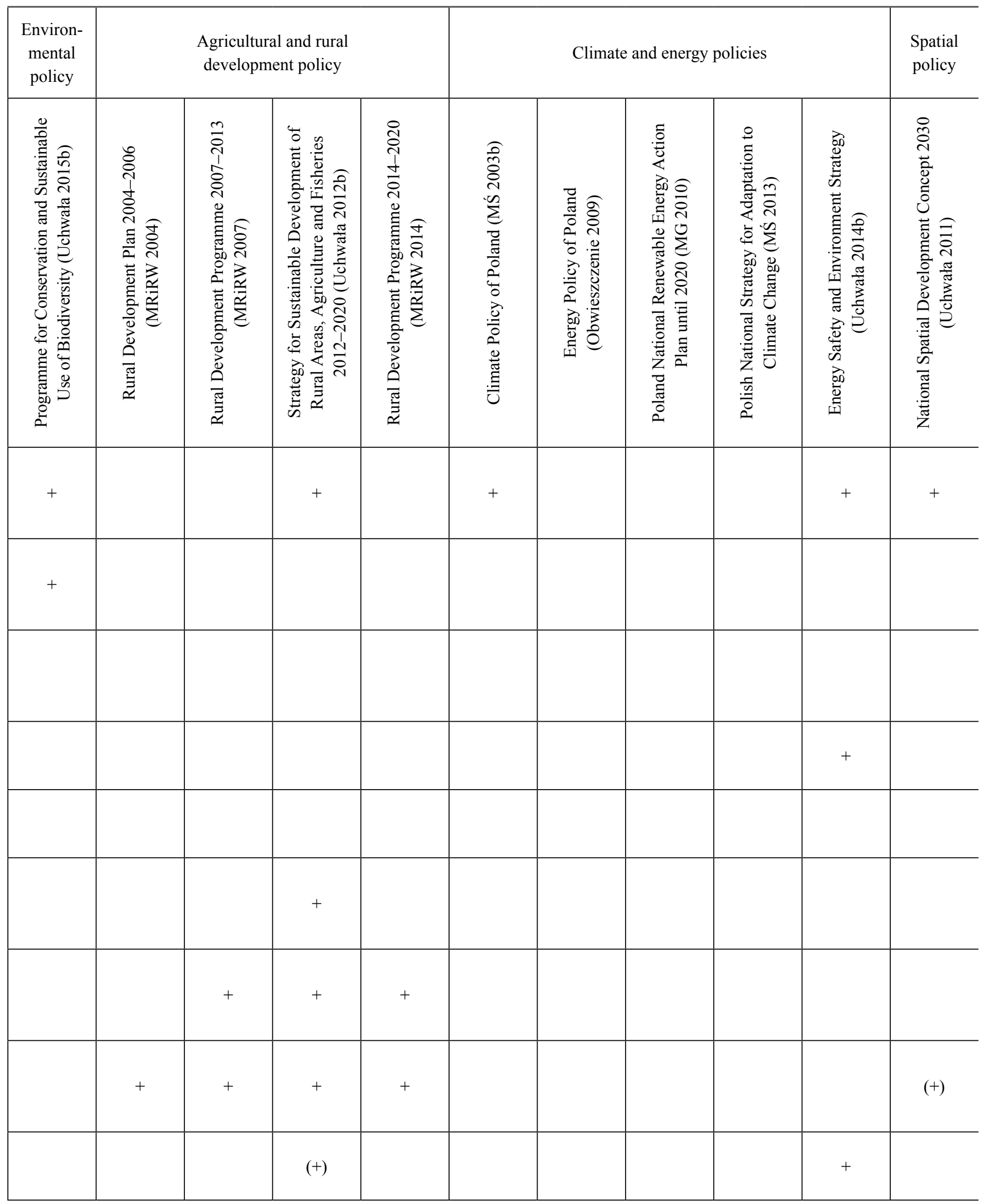




\begin{tabular}{|c|c|c|c|c|c|c|c|}
\hline \multirow{2}{*}{$\begin{array}{l}\text { Policy area } \\
\\
\text { Priority }\end{array}$} & \multicolumn{2}{|c|}{ Forest policy } & \multicolumn{5}{|c|}{ Environmental policy } \\
\hline & 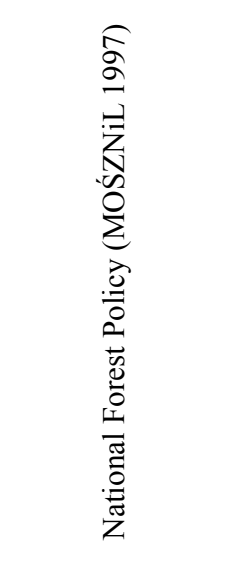 & 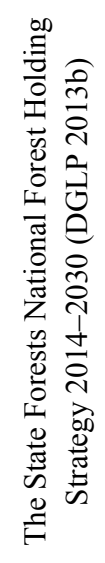 & 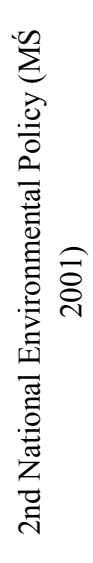 & 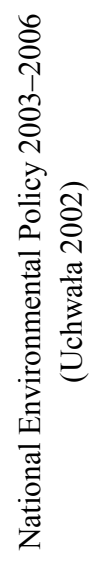 & 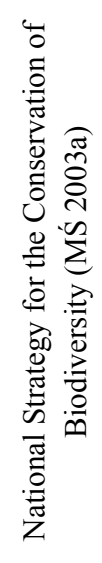 & 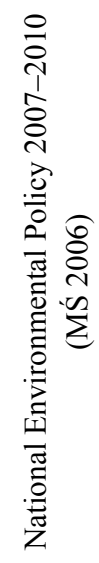 & 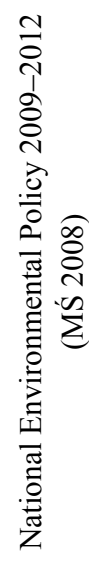 \\
\hline $\begin{array}{l}\text { 9. Forest valuation and } \\
\text { reflecting it in forest-related } \\
\text { policies and programmes }\end{array}$ & No & & & & & & \\
\hline $\begin{array}{l}\text { 10. Improving social aspects of } \\
\text { forest management } \\
\text { including: }\end{array}$ & $\begin{array}{l}\text { Partially } \\
\text { mentioned }\end{array}$ & $(+)$ & $(+)$ & $(+)$ & & & \\
\hline $\begin{array}{l}\text { 11. Securing participation of } \\
\text { all stakeholders in decision- } \\
\text { making, improving forest } \\
\text { communication }\end{array}$ & $\begin{array}{l}\text { Mentioned as } \\
\text { a condition } \\
\text { for policy } \\
\text { implementation }\end{array}$ & & $(+)$ & $(+)$ & $(+)$ & $(+)$ & $(+)$ \\
\hline $\begin{array}{l}\text { 12. Fostering coordination and } \\
\text { cross-sectoral cooperation of } \\
\text { forestry }\end{array}$ & $\begin{array}{l}\text { Mentioned as } \\
\text { a condition } \\
\text { for policy } \\
\text { implementation }\end{array}$ & & & $(+)$ & + & + & \\
\hline $\begin{array}{l}\text { 13. Preserving cultural values of } \\
\text { forests and forest management }\end{array}$ & $\begin{array}{l}\text { Mentioned as } \\
\text { a condition } \\
\text { for policy } \\
\text { implementation }\end{array}$ & & $(+)$ & $(+)$ & & & \\
\hline
\end{tabular}


A. Kaliszewski / Leśne Prace Badawcze, 2018, Vol. 79 (3): 211-227

\begin{tabular}{|c|c|c|c|c|c|c|c|c|c|c|}
\hline $\begin{array}{l}\text { Environ- } \\
\text { mental }\end{array}$ & \multicolumn{4}{|c|}{$\begin{array}{l}\text { Agricultural and rural } \\
\text { development policy }\end{array}$} & \multicolumn{5}{|c|}{ Climate and energy policies } & \multirow{2}{*}{$\begin{array}{c}\text { Spatial } \\
\text { policy }\end{array}$} \\
\hline 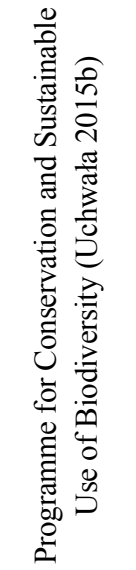 & 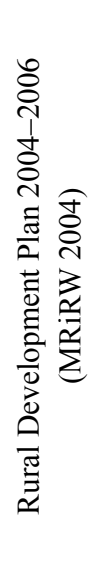 & 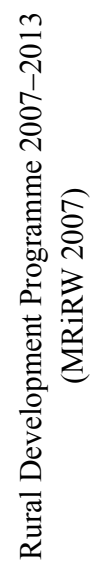 & 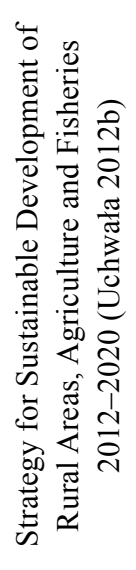 & 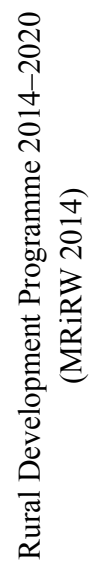 & 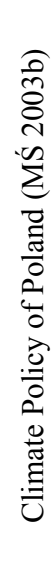 & 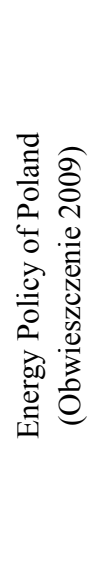 & 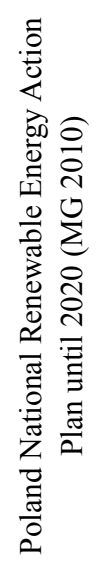 & 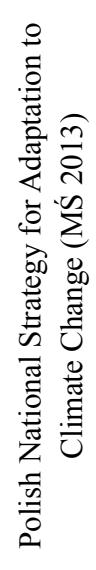 & 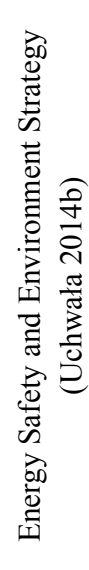 & \\
\hline+ & & & & & & & & & + & \\
\hline & & $(+)$ & & $(+)$ & & & & & $(+)$ & \\
\hline & & + & & + & & & & & + & \\
\hline$(+)$ & & & & & & & & & & $(+)$ \\
\hline+ & & & & & & & & & $(+)$ & $(+)$ \\
\hline$(+)$ & & & $(+)$ & & & & & & $(+)$ & $(+)$ \\
\hline
\end{tabular}




\begin{tabular}{|c|c|c|c|c|c|c|c|}
\hline \multirow[t]{2}{*}{ Policy area } & \multicolumn{2}{|c|}{ Forest policy } & \multicolumn{5}{|c|}{ Environmental policy } \\
\hline & 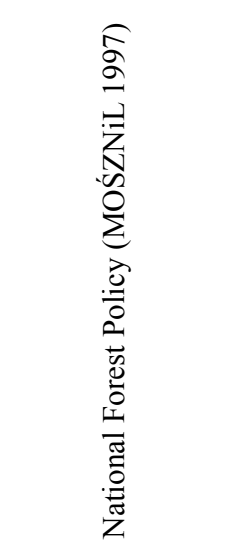 & 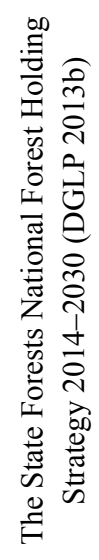 & 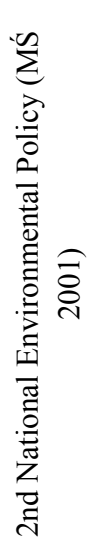 & 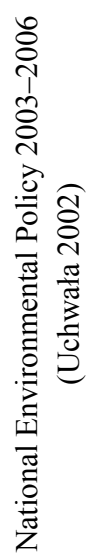 & 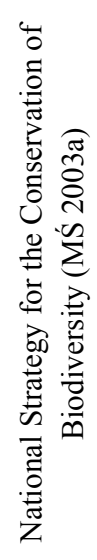 & 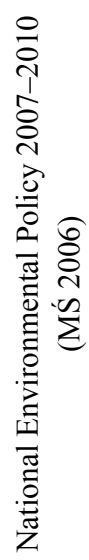 & 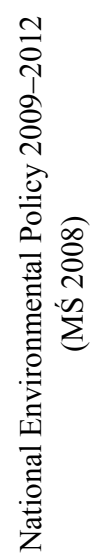 \\
\hline 14. Forest education of society & $\begin{array}{c}\text { Yes - one of the } \\
\text { policy goals }\end{array}$ & + & + & + & + & + & \\
\hline 15. Forest research & $\begin{array}{l}\text { Yes - one of the } \\
\text { policy goals and } \\
\text { condition of its } \\
\text { implementation }\end{array}$ & + & + & + & + & + & + \\
\hline
\end{tabular}

Source: Own elaboration

in the 'The State Forests National Forest Holding Strategy 2014-2030' (DGLP 2013b), stimulating differentiation of sources of income in forestry (partly priority no. 6) to which attention was paid in the 'Strategy for Sustainable Development of Rural Areas, Agriculture and Fisheries 2012-2020' (Uchwała 2012b) and the 'The State Forests National Forest Holding Strategy 2014-2030' (DGLP $2013 \mathrm{~b}$ ), as well as the valuation of all the functions of forest (Uchwała 2012b, Uchwała 2015b). In numerous documents, but in very general terms, it is presented that there is a necessity of ensuring participation of all stakeholders in the process of decision-making concerning natural resources and also developing coordination of actions and cross-sectoral cooperation. These issues are present in all the analysed documents from the field of the environmental policy and in the 'National Spatial Development Concept 2030' (Uchwała 2011).

The second group of documents are national and transregional development strategies. These are the main documents in the field of development policy understood as a 'group of mutually combined actions undertaken and realized in order to ensure permanent and sustainable development of the country, socio-economy consistency, regional and spatial, increasing the competitiveness of the economy and creating new work places in national, regional or local scale' (Ustawa 2006, art. 2). These actions include long-term strategies of national development defying the main goals, challenges and directions for socio-economic development of the country including the role of sustainable development covering a period of at least 15 years ('Poland 2030. Development Challenges', 'Poland 2030. Third Wave of Modernity'), midterm strategies defying the basic conditions, goals and directions of country development in social, economic, regional and spatial terms covering period of 4-10 years ('National Development Strategy 2007-2015', 'National Development Strategy 2020' replaced by 'Strategy for Responsible Development until 2020') and other strategies, including integrated strategies ('National Strategy for Regional Development', 'Strategy for Innovation and 


\begin{tabular}{|c|c|c|c|c|c|c|c|c|c|c|}
\hline $\begin{array}{l}\text { Environ- } \\
\text { mental }\end{array}$ & \multicolumn{4}{|c|}{$\begin{array}{l}\text { Agricultural and rural } \\
\text { development policy }\end{array}$} & \multicolumn{5}{|c|}{ Climate and energy policies } & $\begin{array}{l}\text { Spatial } \\
\text { policy }\end{array}$ \\
\hline 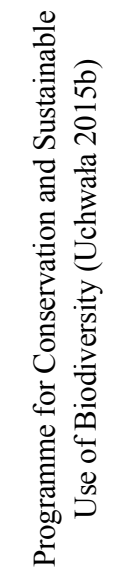 & 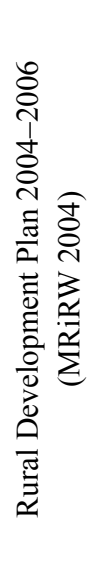 & 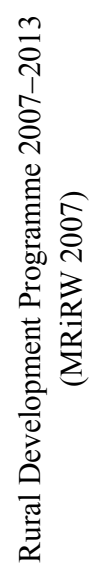 & 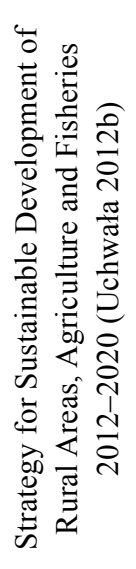 & 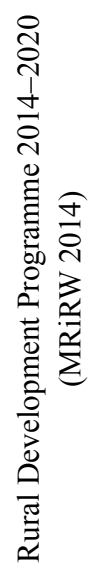 & 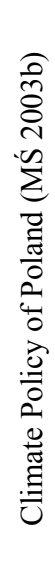 & 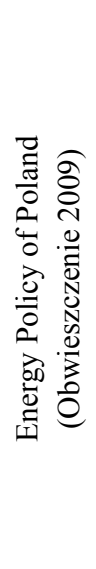 & 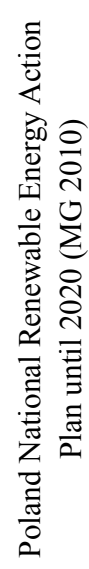 & 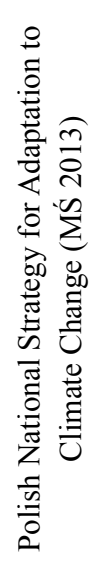 & 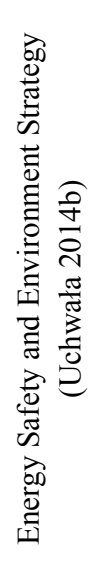 & 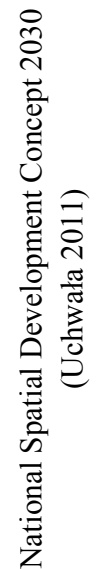 \\
\hline+ & & & & + & & & & & & \\
\hline+ & & & $(+)$ & & + & $(+)$ & $(+)$ & + & + & + \\
\hline
\end{tabular}

Efficiency of the Economy') and transregional ('Strategy for Socioeconomic Development of Eastern Poland until 2020', 'Strategy for Socioeconomic Development of Southern Poland until 2020', 'Strategy for Socioeconomic Development of Western Poland until 2020', 'Strategy for Socioeconomic Development of Central Poland until 2020').

Review of contents of development strategies reveals that majority of them not only do not refer to the discussed priorities of forestry, but also do not include any reference to forests and forest management (see also Rykowski 2013). Forests were not mentioned at all in the 'National Development Strategy 2020' (Uchwała 2012a), the strategy 'Poland 2030. Third Wave of Modernity' (MAiC 2012) and in the 'Strategy for Innovation and Efficiency of the Economy' (Uchwała 2013a). Also, in these three documents, the term 'timber' or 'wood' does not occur - a main product of sustainable forest management. In the 'National Development Strategy 2007-2015' (MRR 2006), forestry was mentioned only while giving the general characteri- stics of agriculture and also in the general description of environment protection and culture, tourism and sport. However, in this document, it was noticed that there is a need for increasing the country's forestation rate. On the other hand, in the 'National Development Strategy 2020' (Uchwała 2012a), attention was paid to the necessity of adaptation of forests to climate change.

Slightly more attention was paid to forests in the strategy 'Poland 2030. Development Challenges' (KPRM 2009). In this document, it was noticed that the value of forests lies not only in landscape values (without any further development of this issue), but it was also indicated that there is a further need for increasing country's forestation rate. In the strategy, wood waste was also listed as a potential source of energy in the context of limiting the use of fossil fuel.

In a similar way, the issues of forests and forestry were placed in all the four transregional strategies. In those documents, besides the occasional invoke, the issue of forestry does not occur. Similarly, as in some of the above discussed national strategies of development, none of the 
Table 2. Inclusion of the priorities for forestry in Europe into national and transregional development strategies Symbols: "+" - a priority directly included; " $(+)$ " - a priority indirectly included; blank field - a priority not included in a document

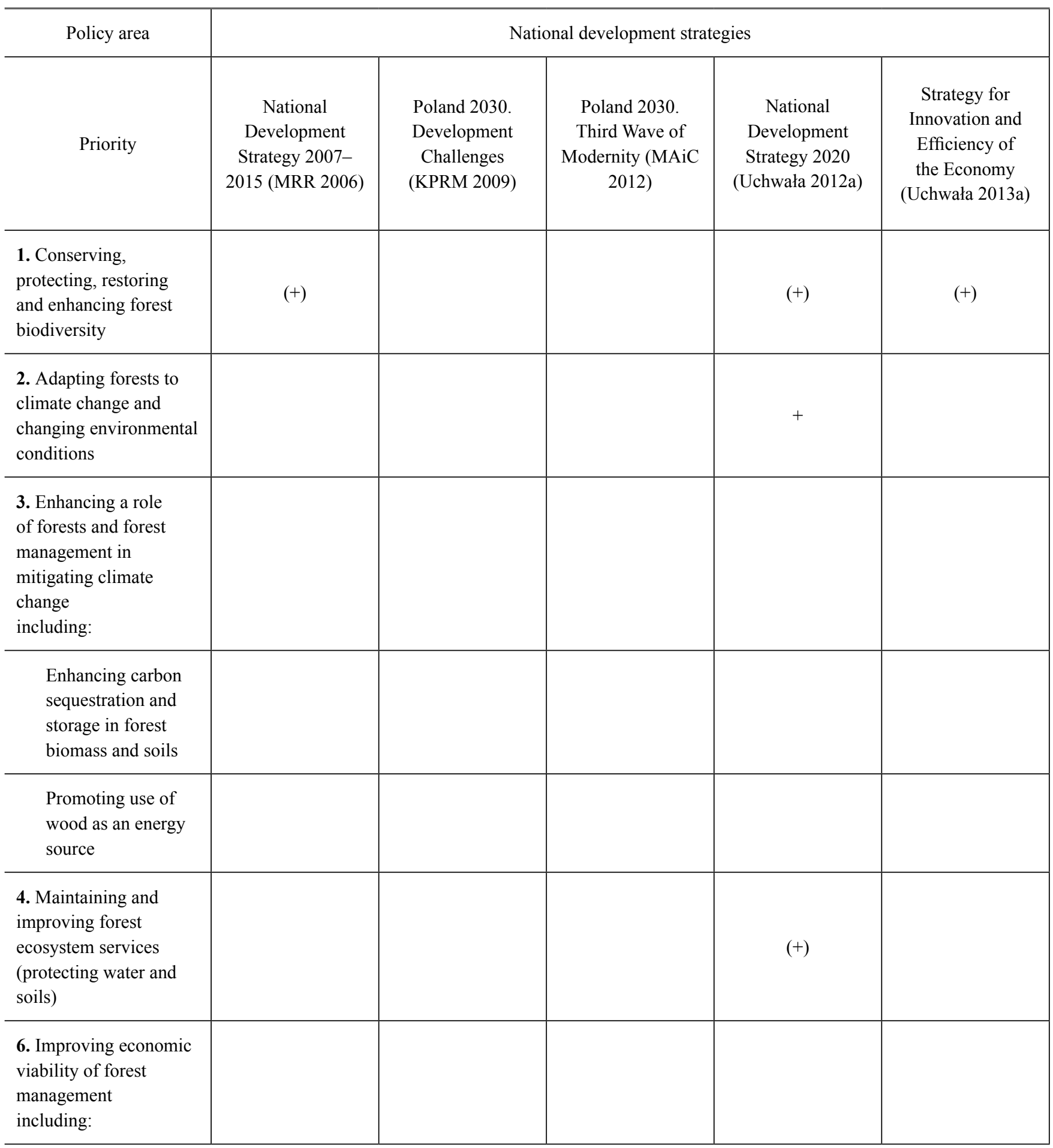




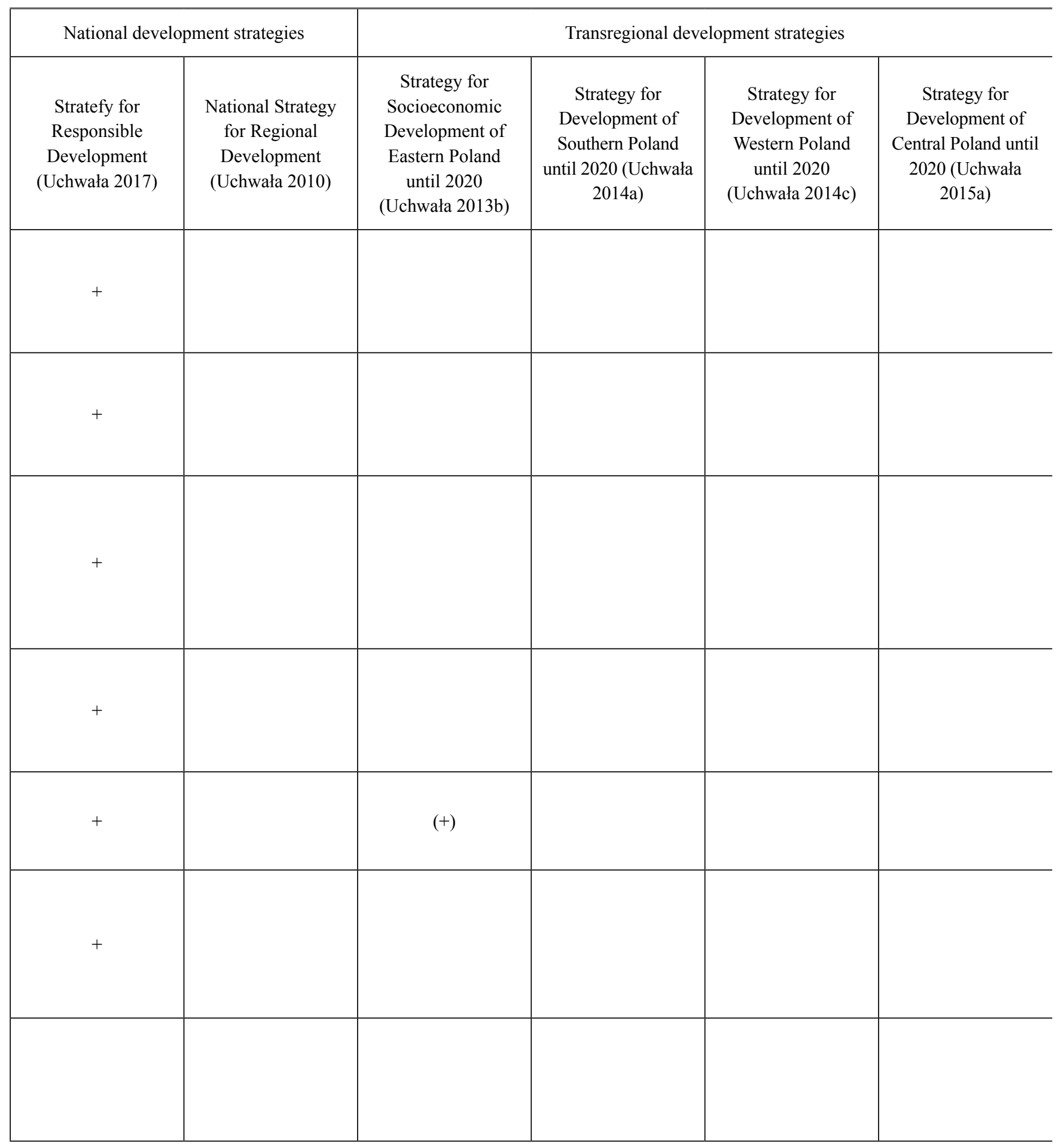




\begin{tabular}{|c|c|c|c|c|c|}
\hline Policy area & \multicolumn{5}{|c|}{ National development strategies } \\
\hline Priority & $\begin{array}{c}\text { National } \\
\text { Development } \\
\text { Strategy 2007- } \\
2015 \text { (MRR 2006) }\end{array}$ & $\begin{array}{l}\text { Poland } 2030 . \\
\text { Development } \\
\text { Challenges } \\
\text { (KPRM 2009) }\end{array}$ & $\begin{array}{c}\text { Poland } 2030 . \\
\text { Third Wave of } \\
\text { Modernity (MAiC } \\
\text { 2012) }\end{array}$ & $\begin{array}{c}\text { National } \\
\text { Development } \\
\text { Strategy 2020 } \\
\text { (Uchwała 2012a) }\end{array}$ & $\begin{array}{l}\text { Strategy for } \\
\text { Innovation and } \\
\text { Efficiency of } \\
\text { the Economy } \\
\text { (Uchwała 2013a) }\end{array}$ \\
\hline \multicolumn{6}{|l|}{$\begin{array}{l}\text { Promoting } \\
\text { production and use } \\
\text { of wood }\end{array}$} \\
\hline $\begin{array}{l}\text { Supporting } \\
\text { innovations in } \\
\text { forestry }\end{array}$ & & & & & $(+)$ \\
\hline $\begin{array}{l}\text { Stimulating } \\
\text { differentiation of } \\
\text { sources of income } \\
\text { in forestry }\end{array}$ & $(+)$ & & & & \\
\hline $\begin{array}{l}\text { 8. Securing contribution } \\
\text { of the forest sector to } \\
\text { a green economy }\end{array}$ & & & & & $(+)$ \\
\hline \multicolumn{6}{|l|}{$\begin{array}{l}\text { 9. Forest valuation and } \\
\text { reflecting it in forest- } \\
\text { related policies and } \\
\text { programmes }\end{array}$} \\
\hline 15. Forest research & & & & & $(+)$ \\
\hline
\end{tabular}

Source: Own elaboration

documents of transregional character uses the terms 'forest' or 'wood'.

In the 'Strategy for Socioeconomic Development of Eastern Poland until 2020' (Uchwała 2013b), only this fact was stated that wood industry is one of the seven most important branches of industry in the region. On the other hand, in the 'Strategy for Development of Western Poland until 2020' (Uchwała 2014c), it was acknowledged that the 'common characteristic of Western Poland's provinces is also strongly developed furniture and wood industry which is based on local resources and traditions'. Therefore, both documents acknowledge the special position of the industry branches based on wood and do not pay attention to it at the same time. This lack of consequence is clearly visible when we take into consideration the fact that on the area covered with both strategies (10 provinces), in total, occurs $67.2 \%$ of all forests and $66.8 \%$ of the national timber resources (GUS 2016).

More attention was given to the discussed issue in the 'National Strategy for Regional Development' (Uchwała 2010). In this document, attention was paid to the necessity of preserving the most valuable areas, in terms of environment, including forests. It was also noticed that there was large meaning of actions supported within the national agricultural policy and common agricultural policy in terms of enhancing the competitiveness of agriculture and forestry for the development of rural areas. The necessity for searching and developing regional potential was also indicated in order to receive energy from renewable sources including biomass. It should be mentioned that the need for develo- 


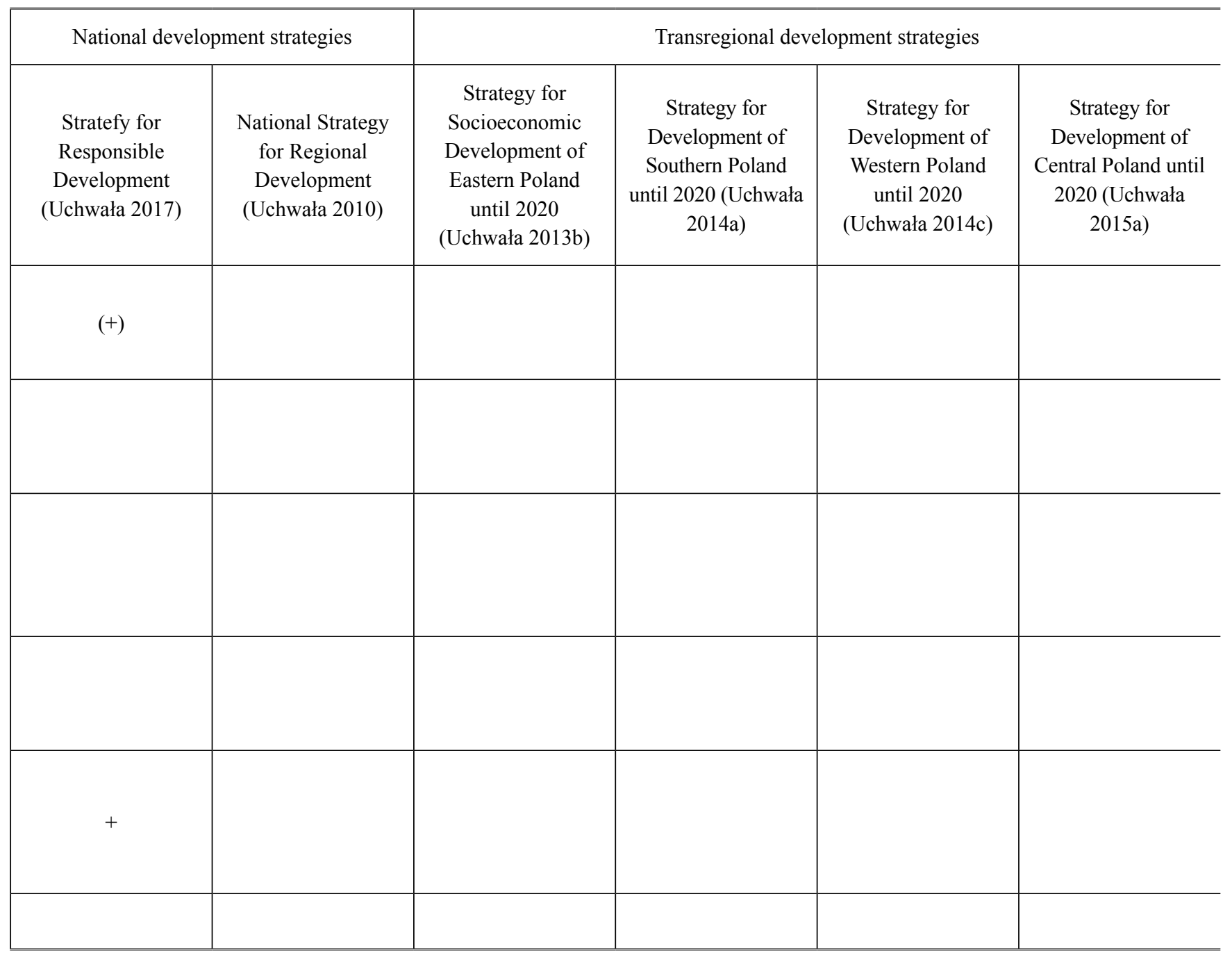

ping renewable sources of energy in connection with biodiversity was also noticed in the 'Strategy for Innovation and Efficiency of the Economy' (Uchwała 2013a).

In comparison to the above discussed development strategies, more attention to forestry was drawn in the 'Strategy for Responsible Development' (Uchwała 2017). It was clearly emphasized in the document that 'multifunctional and sustainable forest management is a guarantee for preserving Poland's environment richness, at the same time, using its resources in order to response to social and economy needs'. The assumptions of the 'Strategy' were realized on the basis of two large strategic projects connected with forests: the 'Complex Programme of Forest and Forestry Adaptation to Climate Change until 2020' and the 'Strategic project of Forest Carbon Farms'. Moreover, in the document, attention was paid to conduct actions that were permanent in nature, including preserving, and if possible, in the context of suitable lands, increasing the general forestation rate of the country, increasing absorption of carbon dioxide by the forests, increasing accessibility of forest biomass (including energy wood) for local needs and co-combustion in power industry, protecting soils from degradation and implementing the $\mathrm{Eu}-$ ropean Landscape Convention.

Positive focus on issues connected with forests and forestry outlined in the 'Strategy for Responsible Development until 2020' (Uchwała 2017) does not significantly change the way forests and forestry are perceived and their role in economic and social development of the country. Forestry matters were either completely omitted in the development strategies of the last twenty years or were brought up frag- 
mentary and in general terms what can be considered a failure of the current forest policy (Rykowski 2013). In this situation, lack of reference in those documents to the identified priorities of the European forest policy should not be surprising (tab. 2).

Priorities of forest policy formulated on the forum of the European Union and under the Forest Europe auspices are present in the Polish forest-focused and forest-related strategies and programmes (environmental protection, biodiversity conservation, agriculture, spatial management, energy). However, they are strongly diffused. Due to lack of current, complex documents on forest policy, the diffusion of forestry issues between numerous documents of different areas of policy of the country raises justified concerns about the inconsistency or even contradictions in realized actions. It may also be a sign of gradual marginalization of forest sector in economic, political and social space, which is visible in realization of the forest priorities 'by the way', while reaching goals in other areas of functioning of the country. This process is particularly visible in numerous national and transregional development strategies adopted in the last two decades. In these priorities, the importance and role of forests is practically not noticeable. Forests as natural resources are excluded from the group of development factors, despite the fact that they cover almost $30 \%$ of the country.

It should be taken into account that the presence of forestry issues in the strategic and programme documents will not cause enhancement of the position of forest sector in political and economy system of the country. The policy is realized by the implementation of its assumptions into legal regulations. That is what makes them normative. Nevertheless, lack of reference to forest and forestry in the most important political documents results in the fact that issues of forests and forestry are almost not present at all in political debates and social awareness campaigns. This has to result in negative consequences for the whole forest sector.

\section{Conclusions}

1. Numerous identified priorities of forest policy adopted on the European level since 1998 do not find their equivalents in notations in the "National Forest Policy" in Poland. However, many of them were expressed directly or indirectly in numerous strategic and programme documents of forestry-related sectors.

2. Forest and forest management issues are completely omitted or brought up occasionally in almost all of the national and transregional development strategies that were developed and adopted within last 20 years. It leads to a conclusion, that forest resources, occupying $30 \%$ of the area of the country, are not actually considered to be a factor of socio-economic development of the country.

3. It should be assumed, that lack of revision and update of notations in the 'National Forest Policy' and the fact of formulation of important goals of forestry in programme documents of other economy sectors may result in generating inconsistency and contradictions in adopted goals and priorities in the field of forest resources management.

4. Lack of revision and updating of notations in the 'Forest National Policy' and the avoidance of issues concerning forests and forestry in the development strategies may lead to gradual marginalization of forest sector in social and political space.

\section{Conflict of interests}

The author declares lack of potential conflicts.

\section{Acknowledgments and source of funding}

In this paper, we presented the results of research realized within the project 'New developments of the national forest policy in the context of changing conditions for forest management in Europe' (no. 240406) financed in the years 2012-2014 by the the Ministry of Science and Higher Education (statutory activity).

\section{References}

Buttolph Johnson J., Reynolds H.T., Mycoff J.D. 2010. Metody badawcze w naukach politycznych. Wydawnictwo Naukowe PWN, Warszawa, 1-633. ISBN 978-83-01-16321-1.

Kaliszewski A. 2018. Cele polityki leśnej w Polsce w świetle aktualnych priorytetów leśnictwa w Europie. Część 2. Priorytety polityki leśnej w Europie. Leśne Prace Badawcze 79(2): 169179. DOI 10.2478/frp-2018-0018.

Kohl M. 2013. Zielona gospodarka - nurt przyszłego rozwoju?, w: Planowanie w gospodarstwie leśnym XXI wieku. Zimowa Szkoła Leśna przy Instytucie Badawczym Leśnictwa, V Sesja. Instytut Badawczy Leśnictwa, Sękocin Stary, 69-73. ISBN 978-83-62830-23-7.

Rykowski K. 2013. Teraźniejszość leśna w strategiach rządowych. Las Polski 6: 7-9.

Streck C., O’Sullivan R., Janson-Smith T., Tarasofsky R. (eds.) 2008. Climate Change and Forests. Emerging Policy and Market Opportunities. Chatham House, London, Brookings Institution Press, Washington D.C, 1-346. ISBN 978-0-8157-0427-0.

Weimer D.L., Vining A.R. 2011. Policy Analysis, Ed. No. 5. Pearson, Boston, 1-473. ISBN 978-0-205-78130-0. 


\section{List of sources}

DGLP 2013. Strategia Państwowego Gospodarstwa Leśnego Lasy Państwowe na lata 2014-2030. Dyrekcja Generalna Lasów Państwowych, Warszawa.

GUS 2016. Leśnictwo 2016. Główny Urząd Statystyczny, Warszawa, 1-365. ISSN 1230-574X.

KPRM 2009. Polska 2030. Wyzwania rozwojowe. Zespół Doradców Strategicznych Prezesa Rady Ministrów, Kancelaria Prezesa Rady Ministrów, Warszawa.

MAiC 2012. Polska 2030. Trzecia fala nowoczesności. Długookresowa Strategia Rozwoju Kraju. Ministerstwo Administracji i Cyfryzacji, Warszawa.

MG 2010. Krajowy plan działania w zakresie energii ze źródeł odnawialnych do 2020 r. Dokument przyjęty w dniu 7 grudnia 2010 r. przez Radę Ministrów. Ministerstwo Gospodarki, Warszawa.

MOŚZNiL 1997. Polityka leśna państwa. Dokument przyjęty przez Radę Ministrów w dniu 22 kwietnia 1997 r. Ministerstwo Ochrony Środowiska, Zasobów Naturalnych i Leśnictwa, Warszawa.

MRiRW 2004. Plan Rozwoju Obszarów Wiejskich na lata 20042006. Ministerstwo Rolnictwa i Rozwoju Wsi, Warszawa.

MRiRW 2007. Program Rozwoju Obszarów Wiejskich na lata 2007-2013 (PROW 2007-2013). Tekst jednolity uwzględniający zmiany zatwierdzone przez Komisję Europejską dnia 24 stycznia 2014 r. Ministerstwo Rolnictwa i Rozwoju Wsi, Warszawa.

MRiRW 2014. Program Rozwoju Obszarów Wiejskich na lata 2014-2020 (PROW 2014-2020). Wersja z dnia 12 grudnia 2014 r. Ministerstwo Rolnictwa i Rozwoju Wsi, Warszawa.

MRR 2006. Strategia rozwoju kraju 2007-2015. Ministerstwo Rozwoju Regionalnego, Warszawa.

MŚ 2001. II Polityka Ekologiczna Państwa. Dokument przyjęty przez Radę Ministrów w czerwcu 2000 r. i Sejm RP w sierpniu 2001 r., Ministerstwo Środowiska, Warszawa.

MŚ 2003a. Krajowa strategia ochrony i umiarkowanego użytkowania różnorodności biologicznej wraz z programem działań. Dokument zatwierdzony przez Radę Ministrów w dniu 25 lutego 2003 r. Ministerstwo Środowiska, Warszawa.

MŚ 2003b. Polityka klimatyczna Polski. Strategie redukcji emisji gazów cieplarnianych w Polsce do roku 2020. Dokument przyjęty przez Radę Ministrów dnia 4 listopada 2003 r. Ministerstwo Środowiska, Warszawa.

MŚ 2006. Polityka ekologiczna państwa na lata 2007-2010 z uwzględnieniem perspektywy na lata 2011-2014. Ministerstwo Środowiska, Warszawa.

MŚ 2008. Polityka ekologiczna państwa w latach 2009-2012 z perspektywą do roku 2016. Ministerstwo Środowiska, Warszawa.

MŚ 2013. Strategiczny plan adaptacji dla sektorów i obszarów wrażliwych na zmiany klimatu do roku 2020 z perspektywą do roku 2030. Ministerstwo Środowiska, Warszawa.
Obwieszczenie 2009. Obwieszczenie Ministra Gospodarki z dnia 21 grudnia 2009 r. w sprawie polityki energetycznej państwa do 2030 r. M.P. $2010 \mathrm{nr} 2$ poz. 11.

Uchwała 2002. Uchwała Sejmu RP z dnia 8 maja 2003 r. w sprawie przyjęcia „Polityki Ekologicznej Państwa na lata 2003-2006 z uwzględnieniem perspektywy na lata 2007-2010”. M.P. 2003 nr 33 poz. 433.

Uchwała 2010. Uchwała Rady Ministrów z dnia 13 lipca 2010 r. Krajowa Strategia Rozwoju Regionalnego 2010-2020: regiony, miasta, obszary wiejskie. M.P. 2010 nr 36 poz. 423.

Uchwała 2011. Uchwała nr 239 Rady Ministrów z dnia 13 grudnia 2011 r. w sprawie przyjęcia Koncepcji Przestrzennego Zagospodarowania Kraju 2030. M.P. 2012 poz. 252.

Uchwała 2012a. Uchwała nr 157 Rady Ministrów z dnia 25 września 2012 r. w sprawie przyjęcia Strategii Rozwoju Kraju 2020. M.P. 2012 poz. 882 .

Uchwała 2012b. Uchwała nr 163 Rady Ministrów z dnia 25 kwietnia 2012 r. w sprawie przyjęcia „Strategii zrównoważonego rozwoju wsi, rolnictwa i rybactwa" na lata 2012-2020. M.P. 2012 poz. 839.

Uchwała 2013a. Uchwała nr 7 Rady Ministrów z dnia 15 stycznia 2013 r. w sprawie Strategii Innowacyjności i Efektywności Gospodarki „Dynamiczna Polska 2020”. M.P. 2013 poz. 73.

Uchwała 2013b. Uchwała nr 121 Rady Ministrów z dnia 11 lipca 2013 r. w sprawie przyjęcia zaktualizowanej „Strategii rozwoju społeczno-gospodarczego Polski Wschodniej do roku 2020". M.P. 2013 poz. 641.

Uchwała 2014a. Uchwała nr 3 Rady Ministrów z dnia 8 stycznia 2014 r. w sprawie przyjęcia „Strategii Rozwoju Polski Południowej do roku 2020". M.P. 2014 poz. 152.

Uchwała 2014b. Uchwała nr 58 Rady Ministrów z dnia 15 kwietnia 2014 r. w sprawie przyjęcia Strategii „Bezpieczeństwo Energetyczne i Środowisko - perspektywa do 2020 r.”. M.P. 2014 poz. 469.

Uchwała 2014c. Uchwała nr 60 Rady Ministrów z dnia 30 kwietnia 2014 r. w sprawie przyjęcia ,Strategii Rozwoju Polski Zachodniej do roku 2020”. M.P. 2014 poz. 452.

Uchwała 2015a. Uchwała nr 107 Rady Ministrów z dnia 14 lipca 2015 r. w sprawie przyjęcia „Strategii Rozwoju Polski Centralnej do roku 2020 z perspektywą 2030”. M.P. 2015 poz. 736.

Uchwała 2015b. Uchwała nr 213 Rady Ministrów z dnia 6 listopada 2015 r. w sprawie zatwierdzenia „Programu ochrony i zrównoważonego użytkowania różnorodności biologicznej wraz z Planem działań na lata 2015-2020”. M.P. 2015 poz. 1207.

Uchwała 2017. Uchwała nr 8 Rady Ministrów z dnia 14 lutego 2017 r. w sprawie przyjęcia Strategii na rzecz Odpowiedzialnego Rozwoju do roku 2020 (z perspektywą do 2030 r.). M.P. 2017 poz. 260.

Ustawa 2006. Ustawa z dnia 6 grudnia 2006 r. o zasadach prowadzenia polityki rozwoju. Dz.U. 2006 nr 227 poz. 1658 z późn. $\mathrm{zm}$. 